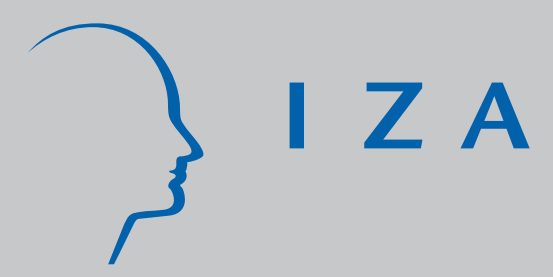

IZA DP No. 5908

R\&D and Employment:

Some Evidence from European Microdata

Francesco Bogliacino

Mariacristina Piva

Marco Vivarelli

August 2011

Forschungsinstitut

zur Zukunft der Arbeit

Institute for the Study

of Labor 


\title{
R\&D and Employment: Some Evidence from European Microdata
}

\author{
Francesco Bogliacino \\ European Commission JRC-IPTS \\ and Universidad EAFIT, RiSE Group \\ Mariacristina Piva \\ Università Cattolica, Milano and Piacenza \\ Marco Vivarelli \\ Università Cattolica, Milano and Piacenza, \\ SPRU-University of Sussex and IZA
}

Discussion Paper No. 5908

August 2011

IZA

P.O. Box 7240

53072 Bonn

Germany

Phone: +49-228-3894-0

Fax: +49-228-3894-180

E-mail: iza@iza.org

Any opinions expressed here are those of the author(s) and not those of IZA. Research published in this series may include views on policy, but the institute itself takes no institutional policy positions.

The Institute for the Study of Labor (IZA) in Bonn is a local and virtual international research center and a place of communication between science, politics and business. IZA is an independent nonprofit organization supported by Deutsche Post Foundation. The center is associated with the University of Bonn and offers a stimulating research environment through its international network, workshops and conferences, data service, project support, research visits and doctoral program. IZA engages in (i) original and internationally competitive research in all fields of labor economics, (ii) development of policy concepts, and (iii) dissemination of research results and concepts to the interested public.

IZA Discussion Papers often represent preliminary work and are circulated to encourage discussion. Citation of such a paper should account for its provisional character. A revised version may be available directly from the author. 
IZA Discussion Paper No. 5908

August 2011

\section{ABSTRACT \\ R\&D and Employment: Some Evidence from European Microdata}

After discussing theory regarding the consequences of technological change on employment and surveying previous microeconometric literature, our aim with this paper is to test the possible job creation effect of business R\&D expenditures, using a unique longitudinal database covering 677 European manufacturing and service firms over the period 19902008. The main outcome from the whole sample dynamic LSDVC (Least Squared Dummy Variable Corrected) estimate is the labour-friendly nature of companies' $R \& D$, the coefficient of which turns out to be statistically significant, although not very large in magnitude. However, the positive and significant impact of R\&D expenditures on employment is detectable in services and high-tech manufacturing but absent in the more traditional manufacturing sectors. This means that we should not expect positive employment effects from increasing R\&D in the majority of industrial sectors. This is something that should be borne in mind by European innovation policy makers having employment as one of their specific aims.

JEL Classification: $\quad 033$

Keywords: innovation, employment, manufacturing, services, LSDVC

Corresponding author:

Marco Vivarelli

Università Cattolica

Facoltà di Economia

Via Emilia Parmense 84

I-29122 Piacenza

Italy

E-mail: marco.vivarelli@unicatt.it

\footnotetext{
* The views expressed are purely those of the author and should not in any circumstances be regarded as representing an official position of the European Commission.
} 
IZA Discussion Paper No. 5908

August 2011

\section{NON-TECHNICAL SUMMARY}

In general terms, the main finding of this study is unequivocal: the labour-friendly nature of companies' R\&D investments clearly turns out to be statistically significant, although not very large in terms of relative magnitude.

This outcome gives further support to the Europe 2020 policy target aiming to increase the European R\&D/GDP ratio, in that it is reassuring as regards the possible employment consequences of increasing R\&D investment across the different countries of the EU. Indeed, the evidence provided supports the view that R\&D expenditures are beneficial not only to European productivity and competitiveness, but also to European job creation capacity.

However, this policy implication should be qualified in two important respects. Firstly, in this study we have focused our attention on one indicator of innovation, i.e. R\&D expenditures. While strictly related to labour-friendly product innovation, this indicator imperfectly captures the alternative mode of technological change, i.e. (possibly) labour-saving process innovation (see Sections 1 and 2). This means that embodied technological change and process innovation, with their possible adverse impacts on employment, are underestimated in this work.

Secondly, what emerges clearly from the empirical analysis is that the positive and significant effect on employment of R\&D expenditures is not equally detectable across the different economic sectors. More specifically, it is evident for services and high-tech manufacturing, but absent for the more traditional manufacturing sectors. This means that we should not expect a positive employment impact from increasing R\&D in most of the industrial sectors. This is something that should be borne in mind by European innovation policy makers considering employment as one of their main targets. 


\section{Introduction}

Assessment of the possible effects of technological change on employment ${ }^{1}$ is an old and controversial issue. Indeed, over the last three decades the diffusion of a 'new economy' based on ICT technologies has led to a re-emergence of the classical debate on the possible adverse effects of innovation on employment. In a nutshell, that debate was characterised by two opposing views. On the one hand, fear of technological unemployment as a direct consequence of labour-saving innovation was the source of social and political concern ${ }^{2}$. On the other, economic theory pointed out the existence of indirect effects which could counterbalance the reduction in employment, due to process innovation incorporated in the new machineries. Indeed, in the first half of the 19th century, classical economists put forward a theory that Marx later called the 'compensation theory’ (see Marx, 1961, vol. 1, chap. 13, and 1969, chap. 18). This theory relies on different market compensation mechanisms which are triggered by technological change itself and which can counterbalance the initial labour-saving impact of process innovation (for an extensive analysis, see also Vivarelli, 1995, chaps. 2 and 3; Petit, 1995; Vivarelli and Pianta, 2000, chap. 2; Spiezia and Vivarelli, 2002; Pianta, 2005).

Compensation mechanisms include both price and income effects. As far as the former are concerned, process innovation leads to a decrease in the unit costs of production, which - in a competitive market - is translated into decreasing prices; in turn, decreasing prices stimulate new demand for products and so additional production and employment ${ }^{3}$. As for the latter, in a world where competitive convergence is not instantaneous, it is observed that during the lag between the decrease in costs due to process innovation and the consequent fall in prices, extra profits and/or extra wages may be accumulated by innovative entrepreneurs and their employees. On the one hand, additional profits may be invested, resulting in the creation of new jobs ${ }^{4}$. On the other, additional wages may translate into higher consumption; in turn, this increase in demand leads to

\footnotetext{
${ }^{1}$ In this paper attention will be focused exclusively on the quantitative employment impact of innovation; for an introduction to the literature on the qualitative effect of technological change on the demand for skills see Berman, Bound and Griliches (1994); Laursen and Foss (2003); Vivarelli (2004); Piva, Santarelli and Vivarelli (2005).

${ }^{2}$ For instance, the response of the English workers to the first industrial revolution was to destroy machines under the charismatic leadership of Ned Ludd in the industrial areas and of Captain Swing in the countryside (see Hobsbawm, 1968; Hobsbawm and Rudé, 1969).

${ }^{3}$ This mechanism was singled out at the very beginning of the history of economic thought (see Say, 1964) and has been re-proposed more recently (see Neary, 1981; Hall and Heffernan, 1985; Dobbs, Hill and Waterson, 1987; Smolny, 1998).

${ }^{4}$ Originally put forward by Ricardo (1951), this argument has also been used by neo-classical thinkers such as Marshall (1961) and later developed into dynamic models by Sylos Labini (1969), Hicks (1973) and Stoneman (1983, pp. 177-81).
} 
an increase in employment which may compensate initial job losses due to process innovation ${ }^{5}$.

Obviously, both the price and income compensation mechanisms may be more or less effective depending on: 1) the degree of market competition (monopolistic rigidities can hinder the decrease in prices due to process innovation); 2) demand elasticity; 3) 'animal spirits' and agents' expectations, which may delay the translation of additional profits and wages into 'effective demand' (for a critique of the compensation theory, see Pasinetti, 1981; Freeman and Soete, 1987; Appelbaum and Schettkat, 1995; Vivarelli, 1995; Pianta, 2005). Moreover, technological change cannot be reduced to process innovation only, since product innovation may imply the birth of entirely new economic branches where additional jobs can be created 6 . Indeed, the labourintensive impact of product innovation was underlined by classical economists (Say, 1964) and even the most severe critic of the compensation theory admitted the positive employment benefits which can derive from this kind of technological change (Marx, 1961, vol. I, p.445). In the current debate, various scholars (Freeman, Clark and Soete, 1982; Katsoulacos, 1986; Freeman and Soete, 1987 and 1994; Vivarelli and Pianta, 2000; Edquist, Hommen and McKelvey, 2001; Bogliacino and Pianta, 2010) agree that product innovations have a positive impact on employment, since they open the way to the development of either entirely new goods or the radical differentiation of mature goods.

Within this framework, in the research presented in this paper we have aimed to test empirically the possible job creation effect of business R\&D expenditures at the firm level ${ }^{7}$.Our study contributes to the empirical microeconometric literature devoted to the link between technology and employment in a number of ways. Firstly, it is the first attempt to assess the impact of R\&D expenditures on employment in a European context; since increasing R\&D is one of the main targets of European economic policy ${ }^{8}$, to assess the possible employment impact of

\footnotetext{
${ }^{5}$ See Pasinetti (1981) and Boyer (1988).

6 Indeed, new products (for instance cars) also displace old products (for instance carriages); however, generally the 'welfare effect' (increasing demand) far exceeds the substitution effect (see Freeman, Clark and Soete, 1982; Katsoulacos, 1984).

${ }^{7}$ It is important to note that the technological indicator used in this study (R\&D) is a better proxy of product than of process innovation. Indeed, while process innovation is mainly incorporated in the new vintages of fixed capital, R\&D is mainly devoted to the promotion of prototypes, the introduction of entirely new products, or the radical differentiation of existing products (see Rosenberg, 1976; Nelson and Winter, 1982; Dosi, 1988). Recent microeconometric studies - using data from the European Community Innovation Surveys (CIS) - have confirmed empirically how R\&D expenditures are closely linked with product innovation, while innovative investment (especially in new machinery and equipment) turns out to be related to process innovation (see Conte and Vivarelli, 2005; Parisi, Schiantarelli and Sembenelli, 2006).

${ }^{8}$ See the Lisbon-Barcelona target, aiming to move the European R\&D/GDP ratio up to $3 \%$, (2\% of which from private companies' R\&D expenditures), recently re-proposed as the 'Innovation Union' flagship strategy (see European
} 
such policy assumes paramount importance for European policy design. Secondly, our microeconometric investigation is based on a unique large and international panel dataset (see Section 3), able to overcome the limitations of previous empirical studies, mainly based on either cross-section analyses, or small longitudinal samples, or single country data (see next section). Thirdly, our proxy for technology is a measurable and continuous variable, while most previous studies have relied on either indirect proxies of technological change or dummy variables (such as the occurrence of product and process innovation). Fourthly, our dataset allows us to disentangle the impact of $R \& D$ on employment over a sectoral dimension, including the possibility of focusing on high-tech manufacturing sectors and service sectors (to our knowledge, only in very few previous microeconometric studies has it been possible to carry out sectoral comparisons; see the next section).

The rest of the paper is organised as follows: Section 2 gives an overview of the empirical literature on the relationship between technological change and employment at the firm level, and also points out some specific methodological issues; Section 3 presents the dataset; Sections 4 and 5 describe our econometric strategy and discuss the results; Section 6 briefly illustrates conclusions and policy implications.

\section{Previous microeconomic empirical literature}

Previous literature devoted to the investigation of the link between technology and employment at the firm level is relatively recent. For instance, Entorf and Pohlmeier (1990) found a positive impact on employment of product innovation, measured using a dummy, in a cross-section of 2,276 West German firms in 1984. The positive impact on employment of product innovation in West German manufacturing was confirmed by Smolny (1998), using a panel of 2,405 firms for the period 1980-1992. Further, using the 1984 British Workplace Industrial Relations Survey, both Machin and Wadhwani (1991) and Blanchflower, Millward and Oswald (1991) found a negative raw correlation between ICT adoption and employment; however, once controlled for workplace characteristics and fixed effects, this correlation turned out to be positive.

Commission 2002 and 2010). 
In contrast with the previous studies, Brouwer, Kleinknecht and Reijnen (1993), using a cross-section of 859 Dutch manufacturing firms, discovered an aggregate negative relationship between aggregate $R \& D$ expenditures and employment (while the opposite emerged when only product innovation was considered). By the same token, Zimmermann (1991), using microdata from 16 German industries, concluded that technological change was one of the determinants of the decrease in employment in Germany during the '80s. Although the impact on employment of innovation is not the main object of the study by Doms, Dunne and Trotske (1997), the authors found that advanced manufacturing technologies, measured by a set of dummy variables, implied higher employment growth in U.S. manufacturing plants over the period 1987-1991. More controversial results come from Klette and Førre (1998). The authors' database comprised 4,333 Norwegian manufacturing plants over the period 19821992; in contrast with most of the other studies, they did not find any clear-cut positive relationship between net job creation and the $R \& D$ intensity of the examined plants.

Most recent studies have taken full advantage of newly-available longitudinal datasets and have applied more sophisticated panel data econometric methodologies. For example, Van Reenen (1997) matched the London Stock Exchange database of manufacturing firms with the SPRU innovation database and obtained a panel of 598 firms over the period 1976-1982. Running GMM-DIF estimates, the author found a positive impact of innovation on employment, and this result turned out to be robust after controlling for fixed effects, dynamics and endogeneity. Similarly, Blanchflower and Burgess (1998) confirmed a positive link between innovation (roughly measured with a dummy) and employment using two different panels of British and Australian establishments; their results proved to be robust after controlling for sectoral fixed effects, size of firm and union density.

An interesting panel analysis was conducted by Greenan and Guellec (2000), using microdata from 15,186 French manufacturing firms over the 1986-1990 period. According to this study, innovating firms, defined according to the outcomes of an innovation survey, create more jobs than non-innovating ones, but the reverse is true at the sectoral level, where the overall effect is negative and only product innovation is job-creating. Interestingly enough, an opposite effect of innovation on employment at the firm and sectoral level may be due to the 'business stealing effect' discussed below (Section 4). However, even when taking the business stealing effect into account, Piva and Vivarelli (2004 and 2005) found evidence in favour of a positive effect of innovation on employment at the firm level. In particular, by applying a GMM- 
SYS methodology to a longitudinal dataset of 575 Italian manufacturing firms over the period 1992-1997, the authors provide evidence of a significant, though small in magnitude, positive link between a firm’s gross innovative investment, and employment.

Using firm-level data (obtained from the third wave of the Community Innovation Survey, CIS) from four European countries (Germany, France, UK, Spain), Harrison, Jaumandreu, Mairesse and Peters (2008) put forward a testable model based on Peters (2004), able to distinguish the relative effects on employment of process and product innovation (discrete variables). The authors conclude that process innovation tends to displace employment, while product innovation is basically labour-friendly. However, compensation mechanisms (see Section 1) are at work, being particularly effective in the service sectors through the increase in demand for the new products. Hall, Lotti and Mairesse (2008) applied a similar model to a panel of Italian manufacturing firms over the period 1995-2003 and found a positive effect on employment of product innovation and no evidence of employment displacement due to process innovation.

More recently, Lachenmaier and Rottmann (2011) have put forward a dynamic employment equation including wages, gross value added, year and industry controls, and alternative proxies (dummies) of current and lagged product and process innovation. Their GMM-SYS estimates based on a very comprehensive dataset of German manufacturing firms over the period 1982-2002 - show a significantly positive impact of different innovation measures on employment. Partially in contrast with previous contributions, the authors found a higher positive impact of process than of product innovation ${ }^{9}$.

In previous literature, empirical analysis has very rarely been carried out according to sectoral belonging. One of the exceptions is the contribution by Greenhalgh, Longland and Bosworth. (2001), developing fixed effects estimates based on a panel of UK firms over the period 1987-1994. Consistently with most of the other studies here discussed, the authors found a positive, albeit modest, effect of R\&D expenditures on employment. However, once they had analysed the data according to firms' sectoral belonging, the positive impact of $\mathrm{R} \& \mathrm{D}$ on employment turned out to be limited solely to the high-tech sectors. In contrast, once they had split the sectors into high-tech and non-high-tech, Lachenmaier and Rottmann (2011) did not find any significant sectoral heterogeneity in the effects that innovation has on employment.

\footnotetext{
${ }^{9}$ However, this result may be due to the discrete nature of the adopted measure of process and product innovation (dummy variables). Interestingly enough, once the authors restrict their attention to (important) product innovation corresponding to patent applications, they found a highly positive and significant employment effect.
} 
As already mentioned, Harrison, Jaumandreu, Mairesse and Peters (2008) distinguished manufacturing from service firms and pointed out the effectiveness of compensation mechanisms and the labour-friendly nature of product innovation. One of the novelties of this paper is the splitting of the sectors, both in terms of manufacturing vs services and of high-tech vs non-hightech. Finally, in a very recent study, Coad and Rao (2011) limit their focus on US high-tech manufacturing industries over the period 1963-2002 and investigate the impact of a composite innovativeness index (comprising information on both $R \& D$ and patents) on employment. The main outcome of their quantile regressions is that innovation and employment are positively linked and that innovation has a stronger impact for those firms that reveal the fastest growth in employment.

On the whole, although previous microeconometric evidence is not fully conclusive about the possible impact of innovation on employment, most recent panel investigations tend to support a positive link, especially when $R \& D$ and/or product innovation are adopted as proxies of technological change and when the focus is on high-tech sectors.

\section{The dataset}

The original microdata strings used in this study were provided by the JRC-IPTS (Joint Research Centre - Institute for Prospective Technological Studies) of the European Commission. The information includes only publicly-traded companies and is extracted from a variety of sources, including companies' annual reports, the Securities and Exchange Commission (SEC) $10-\mathrm{K}$ and $10-\mathrm{Q}$ reports, daily news services and direct company contact ${ }^{10}$. More specifically, this work is limited to a study of EU firms over a period of 19 years (1990-2008). The longitudinal database contains the following information:

- Company identification: name and address, industry sector (Global Industry Classification Standard (GICS), which can be translated into the standard SIC classification);

- Fundamental financial data including income statements, cash flows, taxes, dividends and earnings, pension funds, property assets, ownership data, etc.

- Fundamental economic data, including the crucial information for this study, namely: sales, capital formation, R\&D expenditures, employment and the cost of labour.

\footnotetext{
10 The original source was the Standard\&Poor’s Compustat database.
} 
Data are filed in current national currencies.

Given the crucial role assumed by the $R \& D$ variable in this study, it is worthwhile to discuss in detail what is intended by the $R \& D$ figure. This item represents all costs incurred in the year relating to the development of new products and services. It is important to note that this amount is only the company's contribution and excludes amortization and depreciation of previous investments, so being a genuine flow of current in-house R\&D expenditures ${ }^{11}$. Therefore, the definition of $\mathrm{R} \& \mathrm{D}$ adopted is quite restrictive and refers to the pure flow of current additional resources coming from internal sources and devoted to the launch and development of entirely new products.

It is important to note that the number of years available for each company depends on the company's history; more specifically, a firm enters the database when it first publishes a public financial statement and exits from it in the case of bankruptcy, or if it exits from the relevant market or due to M\&A. In addition, it may well happen that information from the same firm is not continuously available over all the 20 years covered by the statistical sources. Thus, the longitudinal database is unbalanced in nature.

Once we had acquired the rough original IPTS data, we proceeded to construct a consistent longitudinal database that would be adequate for running panel estimations intended to test the relationship between R\&D and employment. For the sake of simplicity, we will describe the complex procedure adopted step by step below.

\section{$\underline{\text { First step: data extraction }}$}

We established the following criteria to guide the extraction of the data from the original IPTS files:

- We selected only those companies with $R \& D>0$ in at least one year of the available time-span;

- We selected only those companies located in the EU 27 countries;

\footnotetext{
${ }^{11}$ In particular this figure excludes: customer or government-sponsored R\&D expenditures; engineering expenses such as routine ongoing engineering efforts to define, enrich or improve the qualities and characteristics of existing products; inventory royalties; market research and testing.
} 
- We extracted information concerning $R \& D$, sales, capital formation, $R \& D$ expenditures, employment and the cost of labour. More specifically, this is the list of the available information for each firm included in the obtained workable dataset:

- country of incorporation (location of the headquarters);

- industry code at 2008;

- R\&D expenses (defined as discussed in the previous sub-section);

- capital expenditures;

- sales;

• employees;

- cost of labour (defined as staff expenses ${ }^{12}$ ).

- We expressed all the value data in the current national currency in millions (for instance, countries which currently use the euro have values in euros for the entire examined period).

- We excluded a minority of unreliable data such as negative sales.

\section{$\underline{\text { Second step: deflation of current nominal values }}$}

Nominal values were translated into constant price values through GDP deflators (source: IMF) centered on the year 2000. For a tiny minority of firms reporting in currencies different from the national currency (i.e. 41 British, 9 Dutch, 4 Irish, 2 Luxembourg, 1 German and 1 Swedish firms reporting in US dollars; 7 British, 2 Danish and 1 Estonian firms reporting in euros), we opted for deflating the nominal values through the national GDP deflator as well.

\section{Third step: values in PPP dollars}

Once we had obtained constant 2000 price values, all figures were converted into US

\footnotetext{
${ }^{12}$ This item represents all direct remunerations to the firm's employees.
} 
dollars using the PPP exchange rate at year 2000 (source: OECD) ${ }^{13}$. 9 companies from 4 countries (Lithuania, Latvia, Malta and Romania) were excluded, due to the unavailability of PPP exchange rates from the OECD. The 10 companies reporting in euros but located in noneuro countries (Denmark, Estonia and the UK) were excluded as well ${ }^{14}$, while the 58 European companies reporting in US dollars were kept as such.

Fourth step: the final format of the panel data

The obtained unbalanced database comprises 804 companies (for a total of 4,244 observations), 2 codes (country and sector) and 5 variables (see the bullet list above) over a period of 19 years (1990-2008).

Since one of our research purposes is to distinguish between manufacturing and service firms and - within manufacturing - high-tech and medium/low-tech sectors ${ }^{15}$, we then added a third code, labelling as High-tech the following sectors ${ }^{16}$ :

- $\quad$ SIC 283: Drugs (ISIC Rev.3, 2423: Pharmaceuticals);

- $\quad$ SIC 357: Computer and office equipment (ISIC Rev.3, 30: Office, accounting and computing machinery);

- $\quad$ SIC 36 (excluding 366): Electronic and other electrical equipment and components, except computer equipment (ISIC Rev.3, 31: Electrical machinery and apparatus);

- $\quad$ SIC 366: Communication equipment (ISIC Rev.3, 32: Radio, TV and communications equipment);

- $\quad$ SIC 372-376: Aircraft and spacecraft (ISIC Rev.3, 353: Aircraft and spacecraft);

- $\quad$ SIC 38: Measuring, analyzing and controlling instruments (ISIC Rev. 3, 33: Medical,

\footnotetext{
${ }^{13}$ This procedure is consistent with that suggested by the Frascati Manual (OECD, 2002) in order to adjust R\&D expenditures correctly for differences in price levels over time (i.e. intertemporal differences requiring deflation) and between countries (i.e. interspatial differences requiring a PPP equivalent). In particular “...the Manual recommends the use of the implicit gross domestic product (GDP) deflator and GDP-PPP (purchasing power parity for GDP), which provide an approximate measure of the average real "opportunity cost" of carrying out the R\&D (ibidem, p. 217). PPP dollars were chosen, since the US dollar is commonly considered the reference currency for global transactions, such as those carried out by the investigated firms.

${ }^{14}$ Given the very small number of firms involved, we decided not to make the arbitrary choice of using either the national or the euro PPA converter.

${ }^{15}$ In this respect - using the same dataset - Ortega-Argilés, Piva, Potters and Vivarelli (2010) found significant sectoral differences in the R\&D-productivity relationship.

${ }^{16}$ We took the standard OECD classification (see Hatzichronoglou, 1997) and extended it to include the entire electrical and electronic sector 36 (considered as a medium-high tech sector by the OECD). We opted for this extension considering that we only compare the high-tech sectors with all the others and that we need an adequate number of observations in the sub-group of high-tech sectors.
} 
precision and optical instruments)

However, as discussed in the next section, our econometric exercise is based on a standard dynamic specification of the demand for labour. Given the unbalanced nature of our longitudinal database, the inclusion of the lagged dependent variable in the estimated specification involved both a reduction in the number of firms (retaining only those firms with at least two consecutive employment data) and a further decrease in the number of observations (initial and isolated data). Therefore, in order to estimate the proposed dynamic specification, we ended up with 677 companies for a total of 3,049 observations. The following Table 1 reports the distribution of the retained firms across the different European countries ${ }^{17}$.

Table 1: Sample composition

\begin{tabular}{|l|c|c|}
\hline COUNTRY & FIRMS & OBS. \\
\hline AUT & 19 & 35 \\
BEL & 20 & 49 \\
CZE & 1 & 3 \\
DEU & 134 & 472 \\
DNK & 25 & 143 \\
ESP & 3 & 5 \\
EST & 2 & 3 \\
FIN & 52 & 142 \\
FRA & 46 & 211 \\
GRC & 16 & 32 \\
HUN & 2 & 7 \\
IRL & 10 & 63 \\
ITA & 5 & 10 \\
LUX & 3 & 5 \\
NLD & 27 & 119 \\
SVN & 1 & 2 \\
SWE & 69 & 388 \\
UK & 242 & 1,360 \\
& & \\
\hline EU & $\mathbf{6 7 7}$ & $\mathbf{3 , 0 4 9}$ \\
\hline
\end{tabular}

\section{Methodological issues and microeconometric strategy}

\footnotetext{
17 Bearing in mind that all the included firms are quoted, some countries, such as the UK, where stock exchange quotation is more common, turn out to be over-represented.
} 
This section is devoted to illustrating the adopted microeconometric strategy, while the following section discusses the results in detail. We start with some methodological notes.

As briefly discussed in Section 1, economic theory cannot provide a clear-cut answer to the question of the employment effect of technological change; therefore attention should be turned to empirical analysis. However, this is not an easy task. Firstly, the microeconometric specification of the employment equation has to take into account the sticky and path-dependent nature of a firm's demand for labour (due to institutional factors such labour protection and high adjustment costs in hiring and firing) and the possible negative impact of wage dynamics. These considerations call for a dynamic (autoregressive) specification of a firm's employment dynamics and for the inclusion of a variable measuring the cost of labour as perceived by the investigated firm (see the specification introduced below).

Secondly, the investigation of the relationship between technological change and employment at the firm level may imply both a 'pessimistic' and an 'optimistic' bias one should be aware of. Starting with the former, it is important to note that microeconometric analyses fully capture the direct labor-saving effect of innovation at the level of the firm, whilst only partially taking into account all the compensation mechanisms briefly discussed in Section 1 (in fact, price and income effects operate within the innovating firm but they also leak out in favour of other firms and sectors). This 'pessimistic' bias makes it more likely that a negative employment impact of innovation will be found, especially when a firm is characterized by the prevalence of process innovation. In this paper, the adopted measure of technological change (R\&D) minimizes the likelihood of this particular bias, since - as discussed above - R\&D expenditures are more closely linked to product than to process innovation.

Thirdly, when dealing only with samples of innovative firms (as is the case in this study), microeconometric studies should take into account the so-called 'business stealing' effect, that is the competitive displacement of laggers and non-innovators. In fact, once the empirical analysis is developed at the level of the single firm, innovative firms tend to be characterized by a better employment performance since they gain market share because of innovation. Indeed, even when innovation is intrinsically labour-saving, simple micro correlations generally show a positive link between technology and employment, since they do not take into account the important effect on rivals, which are crowded out by the innovative firms. In contrast with the pessimistic bias, this optimistic bias makes it more likely that a positive impact of innovation on employment 
will be found, a result which may be reversed at the sectoral and aggregate level. In this respect, the empirical specification should include a demand variable (such as sales) able to check for the business stealing effect (see below).

Bearing these methodological caveats in mind, we now turn our attention to the adopted specification used to investigate the link between R\&D and employment at the firm level.

Consider a perfectly competitive firm maximizing its profits under a CES function of the type:

$$
\text { (1) } \quad \boldsymbol{Y}=\boldsymbol{A}\left[(\alpha \mathbf{L})^{\rho}+(\boldsymbol{\beta K})^{\rho}\right] 1 / \rho
$$

where $Y$ is the output, $L$ and $K$ the inputs, $A$ is a potential Hicks-neutral technological change, and $\alpha$ and $\beta$ are the parameters measuring the reaction of labour and capital to a technological shock and $0<\rho<1$.

If $W$ represents the cost of labour and $P$ is the output price, profit maximization leads to the following labour demand (in logarithm form):

$$
\text { (2) } \quad \ln (\boldsymbol{L})=\ln (\boldsymbol{Y})-\boldsymbol{\sigma} \ln (\boldsymbol{W} / \boldsymbol{P})+(\boldsymbol{\sigma}-1) \ln (\boldsymbol{\alpha})
$$

where $\sigma=1 /(1-\rho)$ is the elasticity of substitution between capital and labour.

The stochastic version of labour demand (2) augmented by including innovation (see Van Reenen, 1997, for a similar approach) for a panel of firms (i) over time (t) is:

\section{(3)}

$$
l_{i, t}=\beta_{1} y_{i, t}+\beta_{2} w_{i, t}+\beta_{3} r \& d_{i, t}+\beta_{4} g i_{i, t}+\left(\varepsilon_{i}+v_{i, t}\right) \quad i=1, . ., n ; t=1, . ., T
$$

where lower-case letters indicate natural logarithms, $l$ is labour, $y$ output (proxied by sales), $w$ wages, $r \& d \mathrm{R} \& \mathrm{D}$ expenditures, $g i$ gross investments, $\varepsilon$ the idiosyncratic individual and timeinvariant firm's fixed effect and $v$ the usual error term ${ }^{18}$.

While specification (3) is static, a dynamic one would be more appropriate for studying the relationship between labour and innovation (see above):

\footnotetext{
${ }^{18}$ Under the assumption that the disturbances are independent across firms.
} 


$$
l_{i, t}=\alpha l_{i, t-1}+\beta_{1} y_{i, t}+\beta_{2} w_{i, t}+\beta_{3} r \& d_{i, t}+\beta_{4} g i_{i, t}+\left(\varepsilon_{i}+v_{i, t}\right)
$$

It is well known that this dynamic specification gives rise to some problems. First of all, the lagged dependent variable $l_{i, t-1}$ is - by construction - correlated with the individual fixed effect $\varepsilon_{i}$ transforming the OLS into a biased and inconsistent estimator. More in general, the OLS estimations do not take into account the unobservable individual effects (in our case a firm's specific characteristics such as managerial capabilities) which may affect both the dependent variable and the regressors. A first available solution for this problem is to compute the within-group estimate based on the inclusion of the fixed effects in the estimation procedure (Fixed Effect estimator). A second solution - in order to wipe out the fixed effects is to switch to the first difference ${ }^{19}$ :

$$
\text { (5) } \Delta l_{i, t}=\alpha \Delta l_{i, t-1}+\beta_{1} \Delta y_{i, t}+\beta_{2} \Delta w_{i, t}+\beta_{3} \Delta r \& d_{i, t}+\beta_{4} \Delta g i_{i, t}+\Delta v_{i, t}
$$

A common problem with this kind of dynamic specification concerns the endogeneity of the lagged dependent variable, i.e. the correlation between $\Delta l_{i, t-1}$ and the error term $\Delta v_{i, t}{ }^{20}$. To solve this problem and to obtain consistent estimates, it is necessary to rely on instrumental variable techniques (Arellano, 1989; Arellano and Bond, 1991; Arellano and Bover, 1995; Ahn and Schmidt, 1995; Blundell and Bond, 1998)21. In particular, Arellano and Bond (1991) introduced the GMM-DIF estimator (first-differenced GMM) as a suitable tool for dealing with the endogeneity of the lagged dependent variable 22 . Blundell and Bond (1998) improved the DIF-estimator, developing the GMM-SYS estimator, more appropriate in the case of high persistency of the dependent variable (i.e. $\alpha$ approaching 1 ).

However, recent econometric literature has revealed that both these GMM-estimators perform poorly when the panel is characterised by a low number of individuals (n). This is our case, since we start from a relatively small number of firms (677), dropping to a very small $n$

\footnotetext{
19 The first difference (following Anderson and Hsiao, 1981) may be more reliable than the within-group estimator, especially when the available panel is limited in its time dimension (see also Van Reenen, 1997, and Baltagi, 2001).

${ }^{20}$ The dependence of $\Delta v_{\mathrm{i}, \mathrm{t}}$ on $v_{\mathrm{i}, \mathrm{t}-1}$ implies that OLS estimates of $\alpha$ in the first-differenced model are inconsistent.

${ }^{21}$ Under the assumption of no serial correlation of the error term in levels, it is possible to use values in level of the dependent variable lagged two periods or more back as instruments. This implies that the number of instruments grows with the time dimension. The instruments in level permit the use of all the available moment conditions (see Arellano and Bond, 1991; Ahn and Schmidt, 1995). In our case, to have valid instruments, it is necessary that the following two conditions are respected: $\mathrm{E}\left(\Delta \mathrm{l}_{\mathrm{i}, \mathrm{t}-1} \mathrm{l}_{\mathrm{i}, \mathrm{t}-\mathrm{s}}\right) \neq 0$, if s $\geq 2$ and $\mathrm{E}\left(\mathrm{l}_{\mathrm{i}, \mathrm{t}-2} \Delta \mathrm{v}_{\mathrm{i}, \mathrm{t}}\right)=0$.

${ }^{22}$ Interestingly enough, the demand for labour was put forward by Arellano and Bond (1991) as the typical example of a dynamic specification where the GMM-DIF appears particularly suitable.
} 
dimension when dealing with service sectors (178) and high-tech manufacturing sectors (152). Therefore, we have used the recently proposed Least Squares Dummy Variable Corrected (LSDVC) estimator. This method has been proposed by Kiviet (1995), Judson and Owen (1999), Bun and Kiviet (2001 and 2003) as being a suitable panel data technique in the case of small samples where GMM cannot be applied efficiently. This procedure is initialised by a dynamic panel estimate (in our case the GMM-SYS one, given the high persistency of our dependent variable), and then relies on a recursive correction of the bias of the fixed effects estimator.

Bruno (2005a and 2005b) has extended the LSDVC methodology to unbalanced panels, such as the one used in this study. The author has tested the behaviour of unbalanced small samples (also making robustness checks according to the different sizes of the samples, various time-spans and alternative unbalanced designs) through Monte Carlo experiments. These experiments have highlighted the fact that the LSDVC estimator is to be preferred to the original LSDV estimator and widely-used GMM estimators when the number of individuals is small and the degree of unbalancedness is severe 23 (Bruno, 2005a).

In accordance with Bun e Kiviet (2001), who demonstrated that the estimated asymptotic standard errors may prove to be poor approximations in small samples, the statistical significance of the LSDVC coefficients has been tested using bootstrapped standard errors (50 iterations; see also Bruno, 2005a).

\section{Results}

As discussed in Section 3, the following estimates are based on a subsample of 677 European firms, for a total of 3,049 observations. The following Table 2 reports the descriptive statistics of the variables (prior to log-transformation) relevant to the regression analysis.

\footnotetext{
${ }^{23}$ Two conditions which are verified in our dataset.
} 
Table 2: Descriptive statistics (677 firms, 3,049 observations)

\begin{tabular}{|c|c|c|c|}
\hline VARIABLES & MEAN & STANDARD & DEVIATION \\
\hline Employment & 20.648 & $\begin{array}{l}\text { Overall } \\
\text { Between } \\
\text { Within }\end{array}$ & $\begin{array}{c}52.121 \\
44.883 \\
9.158\end{array}$ \\
\hline Sales & $6,002.89$ & $\begin{array}{l}\text { Overall } \\
\text { Between } \\
\text { Within }\end{array}$ & $\begin{array}{c}20,587.41 \\
14,510.41 \\
7,946.49\end{array}$ \\
\hline Wages & 107.57 & $\begin{array}{l}\text { Overall } \\
\text { Between } \\
\text { Within }\end{array}$ & $\begin{array}{r}1,063.13 \\
341.84 \\
918.97\end{array}$ \\
\hline R\&D expenditures & 190.96 & $\begin{array}{l}\text { Overall } \\
\text { Between } \\
\text { Within }\end{array}$ & $\begin{array}{l}663.05 \\
440.74 \\
187.24\end{array}$ \\
\hline Gross Investments & 460.87 & $\begin{array}{l}\text { Overall } \\
\text { Between } \\
\text { Within }\end{array}$ & $\begin{array}{r}1,977.46 \\
1,416.50 \\
812.03\end{array}$ \\
\hline
\end{tabular}

Note: employment and wages are expressed in thousands; other values are in millions of PPP US dollars.

As detailed in the previous section, we run regressions of the dynamic labour demand specification (5) using three different methodologies:

- Pooled Ordinary Least Squared (POLS) estimates with heteroskedasticity robust standard errors, checked for time, country and sectoral dummies. Although very preliminary, POLS estimates give an approximate idea of the results. However, it is important to bear in mind that POLS estimates do not control for unobserved individual effects and for the endogeneity of the lagged dependent variable (resulting in over-estimation of the corresponding coefficient);

- Fixed Effects (FE) estimates, checked for time dummies. Much more reliable than POLS, these estimates control for individual unobservables but are still affected by the endogeneity of the lagged dependent variable (resulting in under-estimation of the corresponding coefficient). Using this methodology, individual specific country and sectoral dummies are dropped and absorbed by the individual fixed effect. 
- Least Squared Dummy Variable Corrected (LSDVC) estimates, checked for time dummies. This is the most reliable and complete methodology, controlling for both individual effects and the endogeneity of the lagged dependent variable.

Table 3 reports the results from the POLS, FE and LSDVC estimates. As can be seen, the sticky and path-dependent nature of labour demand is well-confirmed by the large and highly significant coefficient of the lagged dependent variable (ranging from 0.629 to 0.796 ).

Turning our attention to the standard determinants of labour demand, it is worth noting that sales, gross investment and wages all exhibit the expected signs and very significant coefficients (not surprisingly, the largest impact is attributable to output dynamics). As far as our main variable of interest $(R \& D)$ is concerned, the aggregate outcomes seem to suggest a positive and significant relationship between $R \& D$ expenditures and employment, with a coefficient that is always significant at least at the $90 \%$ level of confidence (95\% in the most reliable LSDVC estimate), and showing a magnitude ranging from 0.018 to 0.033 . In general terms, this evidence supports a labour-friendly role for $R \& D$ expenditures. However, the estimated elasticity turns out to be rather low: if a company doubles its $R \& D$ expenditures, the expected increase in its employment is about 2-3\%.

The overall Wald tests on the joint significance of the inserted dummies are always 99\% significant, confirming the need to take into account time, country and sectoral fixed effects where possible. 
Table 3: Econometric results - whole sample

Dependent variable: $\log ($ Employment)

\begin{tabular}{|c|c|c|c|}
\hline & $\begin{array}{c}\text { (1) } \\
\text { POLS }\end{array}$ & $\begin{array}{c}\text { (2) } \\
\text { Fixed Effects }\end{array}$ & $\begin{array}{c}\text { (3) } \\
\text { LSDVC }\end{array}$ \\
\hline Log (Employment-1) & $\begin{array}{c}0.796 * * * \\
(0.016)\end{array}$ & $\begin{array}{c}0.629 * * * \\
(0.098)\end{array}$ & $\begin{array}{c}0.691 * * * \\
(0.015)\end{array}$ \\
\hline Log (Sales) & $\begin{array}{c}0.121^{* * *} \\
(0.016)\end{array}$ & $\begin{array}{c}0.242^{* * *} \\
(0.063)\end{array}$ & $\begin{array}{c}0.212^{* * *} \\
(0.015)\end{array}$ \\
\hline Log(R\&D expenditures) & $\begin{array}{c}0.018^{* * *} \\
(0.004)\end{array}$ & $\begin{array}{l}0.033^{*} \\
(0.018)\end{array}$ & $\begin{array}{l}0.023^{* *} \\
(0.010)\end{array}$ \\
\hline Log(Gross investments) & $\begin{array}{c}0.044^{* * *} \\
(0.007)\end{array}$ & $\begin{array}{c}0.063^{* * *} \\
(0.011)\end{array}$ & $\begin{array}{c}0.064^{* * *} \\
(0.008)\end{array}$ \\
\hline Log(Wages) & $\begin{array}{c}-0.068^{* * *} \\
(0.009)\end{array}$ & $\begin{array}{c}-0.066^{* * *} \\
(0.021)\end{array}$ & $\begin{array}{c}-0.060^{* * *} \\
(0.006)\end{array}$ \\
\hline Constant & $\begin{array}{c}-0.400^{* * *} \\
(0.090)\end{array}$ & $\begin{array}{c}-1.138^{* * *} \\
(0.360)\end{array}$ & \\
\hline $\begin{array}{l}\text { Wald time-dummies } \\
\text { (p-value) }\end{array}$ & $\begin{array}{l}4.75^{* * *} \\
(0.000)\end{array}$ & $\begin{array}{l}2.87 * * * \\
(0.000)\end{array}$ & $\begin{array}{c}48.94^{* * *} \\
(0.000)\end{array}$ \\
\hline $\begin{array}{l}\text { Wald country-dummies } \\
\text { (p-value) }\end{array}$ & $\begin{array}{l}4.15^{* * *} \\
(0.000)\end{array}$ & & \\
\hline $\begin{array}{l}\text { Wald sectoral-dummies } \\
\text { (p-value) }\end{array}$ & $\begin{array}{l}5.18^{* * *} \\
(0.000)\end{array}$ & & \\
\hline & $\begin{array}{r}\mathrm{R}^{2} \\
0.99\end{array}$ & $\begin{array}{c}\mathrm{R}^{2} \text { (within) } \\
0.82\end{array}$ & \\
\hline No. of observations & & 3,049 & \\
\hline No. of firms & & 677 & \\
\hline
\end{tabular}

The following Tables 4, 5, 6, and 7 show the results of testing specification (5) using different sectoral groups, namely manufacturing vs service firms and high-tech manufacturing sectors vs the other manufacturing sectors. 
Table 4: Econometric results - manufacturing sectors

Dependent variable: $\log ($ Employment)

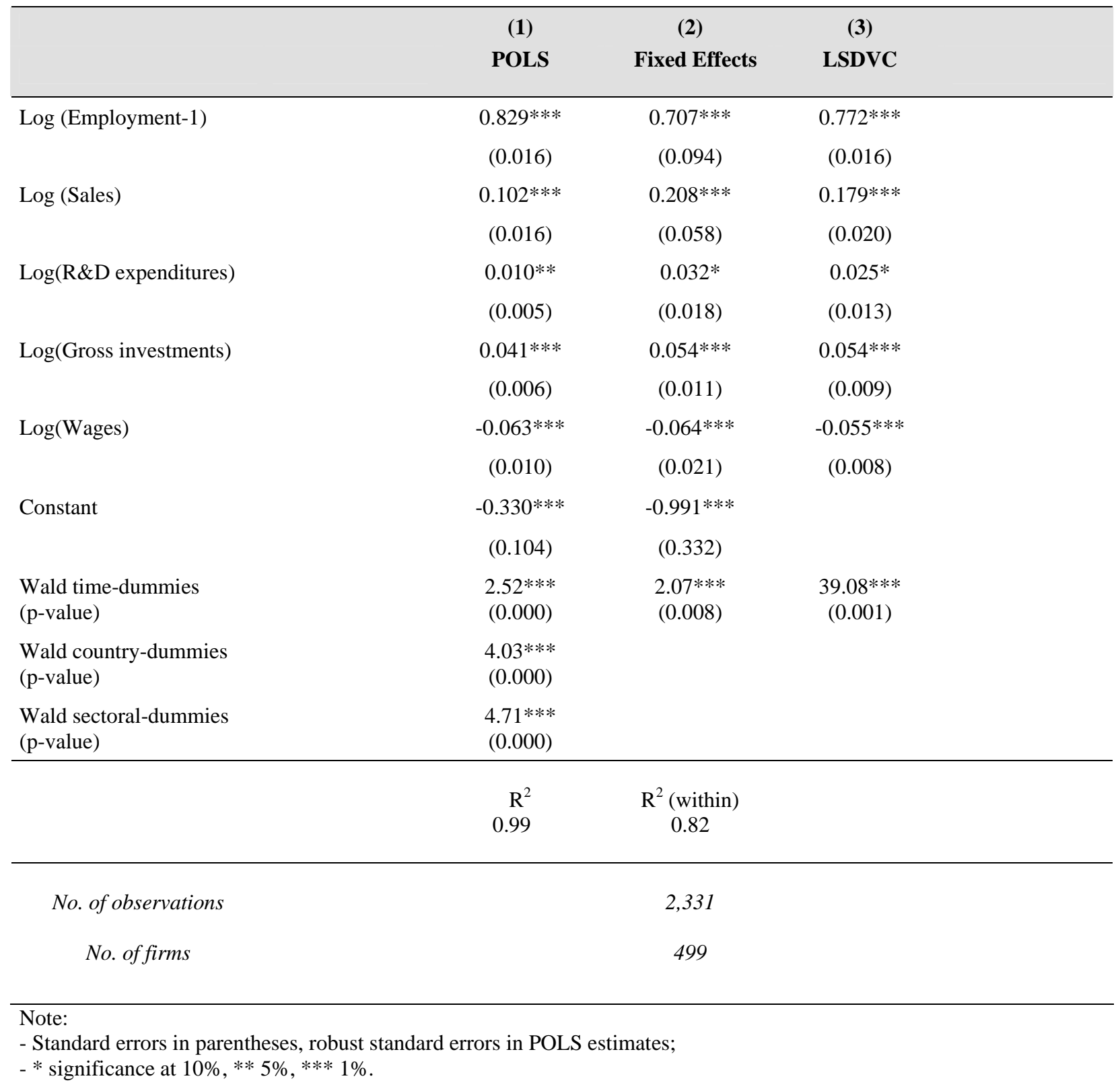


Table 5: Econometric results - service sectors

Dependent variable: $\log ($ Employment)

\begin{tabular}{|c|c|c|c|}
\hline & $\begin{array}{c}\text { (1) } \\
\text { POIS }\end{array}$ & $\begin{array}{c}\text { (2) } \\
\text { Fixed Effects }\end{array}$ & $\begin{array}{c}\text { (3) } \\
\text { SDVC }\end{array}$ \\
\hline \multirow[t]{2}{*}{ Log (Employment-1) } & $0.692 * * *$ & $0.364 * * *$ & $0.425^{* * *}$ \\
\hline & $(0.033)$ & $(0.043)$ & $(0.027)$ \\
\hline \multirow[t]{2}{*}{ Log (Sales) } & $0.194 * * *$ & $0.392 * * *$ & $0.362 * * *$ \\
\hline & $(0.033)$ & $(0.040)$ & $(0.030)$ \\
\hline \multirow[t]{2}{*}{ Log(R\&D expenditures) } & $0.046 * * *$ & $0.068 * * *$ & $0.056^{* *}$ \\
\hline & $(0.010)$ & $(0.027)$ & $(0.022)$ \\
\hline \multirow[t]{2}{*}{ Log(Gross investments) } & $0.047 * * *$ & $0.076^{* * *}$ & $0.075^{* * *}$ \\
\hline & $(0.015)$ & $(0.021)$ & $(0.015)$ \\
\hline \multirow[t]{2}{*}{ Log(Wages) } & $-0.072 * * *$ & $-0.049 * * *$ & $-0.049 * * *$ \\
\hline & $(0.017)$ & $(0.018)$ & $(0.014)$ \\
\hline \multirow[t]{2}{*}{ Constant } & $-0.658 * * *$ & $-2.015^{* * *}$ & \\
\hline & $(0.176)$ & $(0.207)$ & \\
\hline $\begin{array}{l}\text { Wald time-dummies } \\
\text { (p-value) }\end{array}$ & $\begin{array}{l}3.40^{* * *} \\
(0.000)\end{array}$ & $\begin{array}{l}1.99 * * \\
(0.015)\end{array}$ & $\begin{array}{l}24.51^{*} \\
(0.079)\end{array}$ \\
\hline $\begin{array}{l}\text { Wald country-dummies } \\
\text { (p-value) }\end{array}$ & $\begin{array}{l}3.67 * * * \\
(0.000)\end{array}$ & & \\
\hline \multirow[t]{2}{*}{$\begin{array}{l}\text { Wald sectoral-dummies } \\
\text { (p-value) }\end{array}$} & $\begin{array}{l}5.07 * * * \\
(0.000)\end{array}$ & & \\
\hline & $\begin{array}{r}\mathrm{R}^{2} \\
0.99\end{array}$ & $\begin{array}{l}\mathrm{R}^{2} \text { (within) } \\
0.84\end{array}$ & \\
\hline No. of observations & & 718 & \\
\hline No. of firms & & 178 & \\
\hline $0 \%$ & . & & \\
\hline
\end{tabular}


Table 6: Econometric results - high-tech manufacturing sectors

Dependent variable: $\log ($ Employment)

\begin{tabular}{|c|c|c|c|}
\hline & $\begin{array}{c}\text { (1) } \\
\text { POLS }\end{array}$ & $\begin{array}{c}\text { (2) } \\
\text { Fixed Effects }\end{array}$ & $\begin{array}{c}\text { (3) } \\
\text { LSDVC }\end{array}$ \\
\hline Log (Employment-1) & $\begin{array}{c}0.777^{* * *} \\
(0.026)\end{array}$ & $\begin{array}{c}0.465^{* * * *} \\
(0.047)\end{array}$ & $\begin{array}{c}0.544^{* * *} \\
(0.032)\end{array}$ \\
\hline Log (Sales) & $\begin{array}{c}0.115^{* * *} \\
(0.025)\end{array}$ & $\begin{array}{c}0.320 * * * \\
(0.035)\end{array}$ & $\begin{array}{c}0.278 * * * \\
(0.035)\end{array}$ \\
\hline Log(R\&D expenditures) & $\begin{array}{l}0.018^{* *} \\
(0.008)\end{array}$ & $\begin{array}{c}0.059 * * * \\
(0.015)\end{array}$ & $\begin{array}{c}0.049 * * * \\
(0.015)\end{array}$ \\
\hline Log(Gross investments) & $\begin{array}{c}0.057 * * * \\
(0.011)\end{array}$ & $\begin{array}{c}0.050 * * * \\
(0.011)\end{array}$ & $\begin{array}{c}0.050 * * * \\
(0.017)\end{array}$ \\
\hline Log(Wages) & $\begin{array}{c}-0.069 * * * \\
(0.021)\end{array}$ & $\begin{array}{l}-0.040 * \\
(0.025)\end{array}$ & $\begin{array}{c}-0.033^{* *} \\
(0.015)\end{array}$ \\
\hline Constant & $\begin{array}{c}-0.421^{* * *} \\
(0.128)\end{array}$ & $\begin{array}{c}-1.591^{* * *} \\
(0.245)\end{array}$ & \\
\hline $\begin{array}{l}\text { Wald time-dummies } \\
\text { (p-value) }\end{array}$ & $\begin{array}{l}1.74^{* *} \\
(0.035)\end{array}$ & $\begin{array}{l}2.04^{* *} \\
(0.013)\end{array}$ & $\begin{array}{l}15.57 \\
(0.483)\end{array}$ \\
\hline $\begin{array}{l}\text { Wald country-dummies } \\
\text { (p-value) }\end{array}$ & $\begin{array}{c}2.27 * * * \\
(0.005)\end{array}$ & & \\
\hline $\begin{array}{l}\text { Wald sectoral-dummies } \\
\text { (p-value) }\end{array}$ & $\begin{array}{c}3.69 * * * \\
(0.005)\end{array}$ & & \\
\hline & $\begin{array}{r}\mathrm{R}^{2} \\
0.99\end{array}$ & $\begin{array}{l}\mathrm{R}^{2} \text { (within) } \\
0.80\end{array}$ & \\
\hline No. of observations & & 685 & \\
\hline No. of firms & & 152 & \\
\hline
\end{tabular}


Table 7: Econometric results - non high-tech manufacturing

Dependent variable: $\log ($ Employment)

\begin{tabular}{|c|c|c|c|}
\hline & $\begin{array}{l}\text { (1) } \\
\text { POLS }\end{array}$ & $\begin{array}{c}(2) \\
\text { Fixed Effects }\end{array}$ & $\begin{array}{c}\text { (3) } \\
\text { LSDVC }\end{array}$ \\
\hline Log (Employment-1) & $\begin{array}{c}0.851^{* * *} \\
(0.019)\end{array}$ & $\begin{array}{c}0.769 * * * \\
(0.086)\end{array}$ & $\begin{array}{c}0.867 * * * \\
(0.033)\end{array}$ \\
\hline Log (Sales) & $\begin{array}{c}0.105^{* * *} \\
(0.020)\end{array}$ & $\begin{array}{c}0.209 * * * \\
(0.056)\end{array}$ & $\begin{array}{c}0.170 * * * \\
(0.031)\end{array}$ \\
\hline Log(R\&D expenditures) & $\begin{array}{c}0.003 \\
(0.006)\end{array}$ & $\begin{array}{c}0.037 \\
(0.022)\end{array}$ & $\begin{array}{c}0.021 \\
(0.018)\end{array}$ \\
\hline Log(Gross investments) & $\begin{array}{c}0.028 * * * \\
(0.007)\end{array}$ & $\begin{array}{c}0.051 * * * \\
(0.015)\end{array}$ & $\begin{array}{c}0.039 * * \\
(0.019)\end{array}$ \\
\hline Log(Wages) & $\begin{array}{c}-0.059 * * * \\
(0.012)\end{array}$ & $\begin{array}{c}-0.063^{* * *} \\
(0.020)\end{array}$ & $\begin{array}{c}-0.060 * * * \\
(0.008)\end{array}$ \\
\hline Constant & $\begin{array}{c}-0.372^{* * *} \\
(0.132)\end{array}$ & $\begin{array}{c}-1.077^{* * *} \\
(0.301)\end{array}$ & \\
\hline $\begin{array}{l}\text { Wald time-dummies } \\
\text { (p-value) }\end{array}$ & $\begin{array}{l}2.45^{* * *} \\
(0.001)\end{array}$ & $\begin{array}{l}2.30^{* * *} \\
(0.003)\end{array}$ & $\begin{array}{c}43.35^{* * *} \\
(0.000)\end{array}$ \\
\hline $\begin{array}{l}\text { Wald country-dummies } \\
\text { (p-value) }\end{array}$ & $\begin{array}{r}4.27 * * * \\
(0.000)\end{array}$ & & \\
\hline $\begin{array}{l}\text { Wald sectoral-dummies } \\
\text { (p-value) }\end{array}$ & $\begin{array}{r}4.30^{* * * *} \\
(0.000)\end{array}$ & & \\
\hline & $\begin{array}{r}\mathrm{R}^{2} \\
0.99\end{array}$ & $\begin{array}{l}\mathrm{R}^{2} \text { (within) } \\
0.84\end{array}$ & \\
\hline No. of observations & & 1,646 & \\
\hline No. of firms & & 347 & \\
\hline
\end{tabular}

As can be seen, the econometric results concerning the lagged dependent variable, the three standard regressors of the demand for labour (sales, investment, wages) and the diagnostic tests are consistent across all the tables. Therefore, our comments will only focus on the R\&D coefficient and on possible departures from what is shown in Table 3. 
The overall positive employment impact of $R \& D$ expenditures is weakly confirmed in the case of manufacturing firms (in the LSDVC estimate, the coefficient exhibits a magnitude of 0.025 at the $90 \%$ level of statistical significance), while it is more consistently confirmed in the case of services (0.056 at the $95 \%$ level of significance).

Once we split manufacturing into high-tech vs other sectors (see Section 3, step 4), it is interesting to note that the labour-friendly nature of $R \& D$ investment re-emerges as highly significant in the case of the high-tech sectors (0.049 at 99\%), while it is revealed as being not significant - although still positive - in the non-high-tech sectors. This evidence supports the view that the positive impact of employment of $R \& D$ expenditures is detectable in the services and in the high-tech manufacturing sectors, while not relevant in the more traditional manufacturing sectors. Taking into account the theoretical framework and the previous literature discussed in Sections 1 and 2, a possible interpretation of these results is that services and high-tech manufacturing are characterized by a dominant role of product innovation and by more effective 'compensation mechanisms' fostered by increasing demand (see also Harrison, Jaumandreu, Mairesse and Peters, 2008), while more traditional manufacturing sectors are instead characterized by prevailing process innovation and decreasing demand, at least in relative terms.

\section{Conclusions and policy implications}

In general terms, the main finding of this study is unequivocal: the labour-friendly nature of companies’ R\&D investments clearly turns out to be statistically significant, although not very large in terms of relative magnitude.

This outcome gives further support to the Europe 2020 policy target aiming to increase the European $\mathrm{R} \& \mathrm{D} / \mathrm{GDP}$ ratio, in that it is reassuring as regards the possible employment consequences of increasing $R \& D$ investment across the different countries of the EU. Indeed, the evidence provided supports the view that $R \& D$ expenditures are beneficial not only to European productivity and competitiveness, but also to European job creation capacity.

However, this policy implication should be qualified in two important respects. Firstly, in this study we have focused our attention on one indicator of innovation, i.e. R\&D 
expenditures. While strictly related to labour-friendly product innovation, this indicator imperfectly captures the alternative mode of technological change, i.e. (possibly) labour-saving process innovation (see Sections 1 and 2). This means that embodied technological change and process innovation, with their possible adverse impacts on employment, are underestimated in this work.

Secondly, what emerges clearly from the empirical analysis is that the positive and significant effect on employment of R\&D expenditures is not equally detectable across the different economic sectors. More specifically, it is evident for services and high-tech manufacturing, but absent for the more traditional manufacturing sectors. This means that we should not expect a positive employment impact from increasing $R \& D$ in most of the industrial sectors. This is something that should be borne in mind by European innovation policy makers considering employment as one of their main targets. 


\section{References}

Ahn, S. and Schmidt, P. (1995) Efficient Estimation of Models for Dynamic Panel Data, Journal of Econometrics, 68, 5-27.

Anderson, T. W. and Hsiao, C. (1981) Estimation of Dynamic Models with Error Components, Journal of the American Statistical Association, 76, 598-606.

Appelbaum, E. and Schettkat, R. (1995) Employment and Productivity in Industrialized Economies, International Labour Review, 134, 605-23.

Arellano, M. (1989) A Note on the Anderson-Hsiao Estimator for Panel Data, Economics Letters, 31, 337-41.

Arellano, M. and Bond, S. (1991) Some Tests of Specification for Panel Data: Monte Carlo Evidence and an Application to Employment Equations, Review of Economic Studies, 58, 277-97.

Arellano, M. and Bover, O. (1995) Another Look at the Instrumental Variables Estimation of Error-components Models, Journal of Econometrics, 68, 29-51.

Baltagi, B.H. (2001) Econometric Analysis of Panel Data, Wiley, Chichester, 2nd ed.

Berman, E., Bound, J. and Griliches, Z. (1994) Changes in the Demand for Skilled Labor within U.S. Manufacturing Industries: Evidence from the Annual Survey of Manufacturing, Quarterly Journal of Economics, 109, 367-97.

Blanchflower, D. and Burgess, S.M. (1998) New Technology and Jobs: Comparative Evidence from a Two-country Study, Economics of Innovation and New Technology, 5, 109-38.

Blanchflower, D., Millward, N. and Oswald, A. (1991) Unionisation and Employment Behaviour, Economic Journal, 101, 815-34.

Blundell, R. and Bond, S. (1998) Initial Conditions and Moment Restrictions in Dynamic Panel Data models, Journal of Econometrics, 87, 115-43.

Bogliacino, F. and Pianta, M. (2010) Innovation and Employment: a Reinvestigation Using Revised Pavitt Classes, Research Policy, 3, 799-809.

Boyer, R. (1988) New Technologies and Employment in the 1980s: From Science and Technology to Macroeconomic Modelling, in J.A. Kregel - E. Matzner - A. Roncaglia (eds), Barriers to Full Employment, Macmillan, London, 233-68.

Brouwer, E., Kleinknecht, A. and Reijnen, J.O.N. (1993) Employment Growth and Innovation at the Firm Level: An Empirical Study, Journal of Evolutionary Economics, 3, 153-59.

Bruno, G.S.F. (2005a) Estimation and Inference in Dynamic Unbalanced Panel Data Models with a Small Number of Individuals, The Stata Journal, 5, 473-500.

Bruno, G.S.F. (2005b) Approximating the Bias of the LSDV Estimator for Dynamic Unbalanced Panel Data Models, Economics Letters, 87, 361-66.

Bun, M.J.G. and Kiviet, J.F. (2001) The Accuracy of Inference in Small Samples of Dynamic Panel Data Models, Tinbergen Institute Discussion Paper TI 2001-006/4.

Bun, M.J.G. and Kiviet, J.F. (2003) On the Diminishing Returns of Higher Order Terms in Asymptotic Expansions of Bias, Economics Letters, 79, 145-52. 
Coad, A. and Rao, R. (2011) The Firm-Level Employment Effects of Innovations in Hightech US Manufacturing Industries, Journal of Evolutionary Economics, forthcoming.

Conte, A. and Vivarelli, M. (2005) One or Many Knowledge Production Functions? Mapping Innovative Activity Using Microdata, IZA Discussion Paper, No. 1878, Bonn.

Dobbs, I.M., Hill, M.B. and Waterson, M. (1987) Industrial Structure and the Employment Consequences of Technical Change, Oxford Economic Papers, 39, 552-67.

Doms, M., Dunne, T. and Trotske, K. (1997) Workers, Wages, and Technology, Quarterly Journal of Economics, 112, 253-89.

Dosi, G. (1988) Source, Procedure and Microeconomic Effects of Innovation, Journal of Economic Literature, 26, 1120-71.

Edquist, C., Hommen, L. and McKelvey, M. (2001) Innovation and Employment: Product Versus Process Innovation, Elgar, Cheltenham.

Entorf, H. and Pohlmeier, W. (1990) Employment, Innovation and Export Activities, in J.P. Florens, M. Ivaldi, J.J. Laffont and F. Laisney (eds), Microeconometrics: Surveys and Applications, Basil Blackwell, Oxford, 394-415.

European Commission (2002), More research for Europe. Towards 3\% of GDP, COM(2002) 499 final, Brussels.

European Commission (2010) Communication from the Commission to the European Parliament, the Council, the European Economic and Social Committee and the Committee of the Regions. Europe 2020 Flagship Initiative Innovation Union. SEC(2010) 1161.

Freeman, C. and Soete, L. (eds) (1987) Technical Change and Full Employment, Basil Blackwell, Oxford.

Freeman, C. and Soete, L. (1994) Work for All or Mass Unemployment? Computerised Technical Change into the Twenty-first Century, Pinter, London-New York.

Freeman, C., Clark, J. and Soete, L. (1982) Unemployment and Technical Innovation, Pinter, London.

Greenan, N. and Guellec, D. (2000) Technological Innovation and Employment Reallocation, Labour, 14, 547-90.

Greenhalg, C., Longland, M. and Bosworth, D. (2001) Technological Activity and Employment in a Panel of UK Firms, Scottish Journal of Political Economy, 48, 260-282.

Hall, P.H. and Heffernan, S.A. (1985) More on the Employment Effects of Innovation, Journal of Development Economics, 17, 151-62.

Hall, B.H., Lotti, F. and Mairesse, J. (2008) Employment, Innovation, and Productivity: Evidence from Italian Microdata, Industrial and Corporate Change, 17, 813-39.

Harrison, R., Jaumandreu, J., Mairesse, J. and Peters, B. (2008) Does Innovation Stimulate Employment? A Firm-Level Analysis Using Comparable Micro-Data from Four European Countries, NBER Working Papers, No. 14216, Cambridge MA.

Hicks, J.R. (1973) Capital and Time, Oxford University Press, Oxford.

Hatzichronoglou, T. (1997) Revision of the High-Technology Sector and Product Classification, OECD Science, Technology and Industry Working Papers, OECD, Paris. 
Hobsbawm, E.J. (1968) Industry and Empire: An Economic History of Britain since 1750, Penguin Books, Harmondsworth Middlesex.

Hobsbawm, E.J. and Rudé, G. (1969) Captain Swing, Lawrence \& Wishart, London.

Judson, R.A. and Owen, A.L. (1999) Estimating Dynamic Panel Data Models: A Guide for Macroeconomists, Economics Letters, 65, 9-15.

Katsoulacos, Y.S. (1984), Product Innovation and Employment, European Economic Review, 26, 83-108.

Katsoulacos, Y.S. (1986) The Employment Effect of Technical Change, Wheatsheaf, Brighton.

Kiviet, J.F. (1995) On Bias, Inconsistency and Efficiency of Various Estimators in Dynamic Panel Data Models, Journal of Econometrics, 68, 53-78.

Klette, T.J. and Førre, S.E. (1998) Innovation and Job Creation in a Small Open Economy: Evidence from Norwegian Manufacturing Plants 1982-92, Economics of Innovation and New Technology, 5, 247-72.

Lachenmaier, S. and Rottmann, H. (2011), Effects of Innovation on Employment: A Dynamic Panel Analysis, International Journal of Industrial Organization, 29, 210-220.

Laursen, K. and Foss, N. (2003) New Human Resource Management Practices, Complementarities and the Impact in Innovation Performance, Cambridge Journal of Economics, 27, 243-63.

Machin, S. and Wadhwani, S. (1991) The Effects of Unions on Organisational Change and Employment: Evidence from WIRS, Economic Journal, 101, 324-30.

Marshall, A. (1961) Principles of Economics, Macmillan, Cambridge, first edn 1890.

Marx, K. (1961) Capital, Foreign Languages Publishing House, Moscow, first edn 1867.

Marx, K. (1969) Theories of Surplus Value, Lawrence \& Wishart, London, first edn.1905-10.

Neary, J.P. (1981) On the Short-run Effects of Technological Progress, Oxford Economic Papers, 32, 224-33.

Nelson, R.R. and Winter, S. (1982) An Evolutionary Theory of Economic Change, Harvard University Press, Harvard.

OECD (2002) Frascati Manual - Proposed Standard Practice for Surveys on Research and Experimental Development, Paris.

Ortega-Argilés R., Piva, M., Potters, L. and Vivarelli, M. (2010) Is Corporate R\&D Investment in High-Tech Sectors more Effective?, Contemporary Economic Policy, 28, 353-65.

Parisi, M. L., Schiantarelli, F. and Sembenelli, A. (2006) Productivity, Innovation and R\&D: Micro Evidence for Italy, European Economic Review, 50, 2037-61.

Pasinetti, L. (1981) Structural Change and Economic Growth, Cambridge University Press, Cambridge.

Peters, B. (2004) Employment Effects of Different Innovation Activities: Microeconometric Evidence, ZEW Discussion Papers, No. 0473, Bonn.

Petit, P. (1995) Employment and Technological Change, in P. Stoneman (Ed), Handbook of the Economics of Innovation and Technological Change, North Holland, Amsterdam, 366-408.

Pianta, M. (2005) Innovation and Employment, in Fagerberg, J. - Mowery, D. - Nelson, R. 
(eds) The Oxford Handbook of Innovation, Oxford University Press, Oxford, 568-98.

Piva, M. and Vivarelli, M. (2004) Technological Change and Employment: Some Micro Evidence from Italy, Applied Economics Letters, 11, 373-76.

Piva, M. and Vivarelli, M. (2005) Innovation and Employment: Evidence from Italian Microdata, Journal of Economics, 86, 65-83.

Piva, M., Santarelli, E. and Vivarelli, M. (2005) The Skill Bias Effect of Technological and Organizational Change: Evidence and Policy Implications, Research Policy, 34, 14157.

Ricardo, D. (1951) Principles of Political Economy, in P. Sraffa (Ed.), The Works and Correspondence of David Ricardo, Cambridge University Press, Cambridge, vol. 1, third edn 1821.

Rosenberg, N. (1976) Perspectives on Technology, Cambridge University Press, Cambridge.

Say, J.B. (1964) A Treatise on Political Economy or the Production, Distribution and Consumption of Wealth, M. Kelley, New York, first edn 1803.

Smolny, W. (1998) Innovations, Prices and Employment: A Theoretical Model and an Empirical Application for West German Manufacturing Firms, Journal of Industrial Economics, 46, 359-81.

Spiezia, V. and Vivarelli, M. (2002) Innovation and Employment: a Critical Survey, in Greenan, N. - L'Horty Y. - Mairesse, J. (eds.), Productivity, Inequality and the Digital Economy: A Transatlantic Perspective, MIT Press, Cambridge (Mass.), 101-31.

Stoneman, P. (1983) The Economic Analysis of Technological Change, Oxford University Press, Oxford.

Sylos Labini, P. (1969) Oligopoly and Technical Progress, Harvard University Press, Cambridge MA, first edn 1956.

Van Reenen, J. (1997) Employment and Technological Innovation: Evidence from U.K. Manufacturing Firms, Journal of Labour Economics, 15, 255-84.

Vivarelli, M. (1995) The Economics of Technology and Employment: Theory and Empirical Evidence, Elgar, Aldershot.

Vivarelli, M. (2004) Globalization, Skills and Within-Country Income Inequality in Developing Countries, in Lee, E. - Vivarelli, M. (eds.), Understanding Globalization, Employment and Poverty Reduction, Palgrave Macmillan, New York, 211-43.

Vivarelli, M. and Pianta, M. (eds) (2000), The Employment Impact of Innovation: Evidence and Policy, Routledge, London.

Zimmermann, K. (1991) The Employment Consequences of Technological Advance: Demand and Labour Costs in 16 German Industries, Empirical Economics, 16, 253-66. 